Volume 6

Issue 2 Special Issue: The Role of Technology

Article 15

and Innovation in Patient Experience

2019

\title{
"Anyone can co-design?": A case study synthesis of six experience-based co-design (EBCD) projects for healthcare systems improvement in New South Wales, Australia
}

\author{
Tara L. Dimopoulos-Bick \\ Agency for Clinical Innovation, New South Wales, Australia \\ Claire O'Connor \\ Agency for Clinical Innovation, New South Wales, Australia \\ Jane Montgomery \\ Agency for Clinical Innovation, New South Wales, Australia \\ Tracey Szanto \\ Agency for Clinical Innovation, New South Wales, Australia \\ Marion Fisher \\ Agency for Clinical Innovation, New South Wales, Australia
}

See next page for additional authors

Follow this and additional works at: https://pxjournal.org/journal

Part of the Health and Medical Administration Commons, Health Policy Commons, Health Services Administration Commons, and the Health Services Research Commons

\section{Recommended Citation}

Dimopoulos-Bick TL, O'Connor C, Montgomery J, Szanto T, Fisher M, Sutherland V, Baines H, Orcher P, Stubbs J, Maher L, Verma R, Palmer VJ. "Anyone can co-design?": A case study synthesis of six experience-based co-design (EBCD) projects for healthcare systems improvement in New South Wales, Australia. Patient Experience Journal. 2019; 6(2):93-104. doi: 10.35680/2372-0247.1365. 
"Anyone can co-design?": A case study synthesis of six experience-based codesign (EBCD) projects for healthcare systems improvement in New South Wales, Australia

\section{Cover Page Footnote}

This article is associated with the Innovation \& Technology lens of The Beryl Institute Experience Framework. (http://bit.ly/ExperienceFramework). You can access other resources related to this lens including additional PXJ articles here: http://bit.ly/PX_InnovTech

\section{Authors}

Tara L. Dimopoulos-Bick, Claire O'Connor, Jane Montgomery, Tracey Szanto, Marion Fisher, Violeta Sutherland, Helen Baines, Phillip Orcher, John Stubbs, Lynne Maher, Raj Verma, and Victoria J. Palmer 


\title{
"Anyone can co-design?": A case study synthesis of six experience-based co-design (EBCD) projects for healthcare systems improvement in New South Wales, Australia
}

\author{
Tara L. Dimopoulos-Bick, Agency for Clinical Innovation, tara.dimopoulosbick@health.nsw.gov.au \\ Claire O'Connor,Agency for Clinical Innovation,Claire.OConnon@health.nsw.gov.au \\ Jane Montgomery, Agency for Clinical Innovation, Jane.Montgomery@health.nsw.gov.au \\ Tracey Szanto, Agency for Clinical Innovation, Tracey.Szanto@health.nsw.gov.au \\ Marion Fisher, Agency for Clinical Innovation, Marion.Fisher@health.nsw.gov.au \\ Violeta Sutherland, Agency for Clinical Innovation,Violeta.Sutherland@,health.nsw.gov.au \\ Helen Baines, Hunter New England Local Health District, Helen.Baines@hnehealth.nsw.gov.au \\ Phillip Orcher, Agency for Clinical Innovation, Phillip.Orcher@bealth.nsw.gov.au \\ John Stubbs, Agency for Clinical Innovation, jnj@bigpond.net.au \\ Lynne Maher, 3. Ko Awatea Counties Manukau Health,ynne.maher@middlemore.co.nz. \\ Raj Verma, Agency for Clinical Innovation, Raj.Verma@health.nsw.gov.au \\ Victoria J. Palmer, The Department of General Practice, Melbourne Medical School, The University of Melbourne, \\ v.palmer@unimelb.edu.au
}

\begin{abstract}
Experience-based co-design (EBCD) is a quality improvement approach that is being used internationally to bring service users and health professionals together to improve healthcare experiences, systems and processes. Early evaluations and case studies of EBCD have shown promise in terms of improvements to experience and organisational processes, however challenges remain in participation around shared power and decision making, mobilisation for implementation, sustainment of improvements and measurement of outcomes. The objective of this case study was to explore the emergent issues in EBCD participation and implementation in six quality improvement projects conducted in mental health, rehabilitation, blood and bone marrow transplant, brain injury rehabilitation, urinary incontinence and intellectual disability settings by the Agency for Clinical Innovation (ACI), New South Wales, Australia (2015-2018). Methods: A two stage process of analysis was employed. The first stage involved a case to case synthesis using a variable-oriented approach. In this approach themes were identified within individual cases and compared across cases in workshops with all project leads. In the second stage the case themes were synthesised within an overarching thematic that was identified as the main challenge in effective participation and implementation in these EBCD projects. The results: themes identified in the first stage of analysis related to different methods for gathering experiences and the activities used for the co-design of improvements. Variability in service user participation within co-design workshops was also discussed. Four out of the six projects implemented improvements in full. The prominent thematic overarching all six EBCD cases was the need for guidance on capability development and co-design preparedness for all participants in co-design not only project leads. In conclusion, variability in EBCD implementation makes it difficult to identify which component parts are essential for improving experiences and services, and which of these lead to sustained changes and benefits for service users and health professionals. One way to address this is to develop a model for codesign capability and preparedness that is closely linked with a set of eight mechanisms that have been previously identified as essential to achieving change in healthcare improvement initiatives.
\end{abstract}

\section{Keywords}

Experience-based co-design, co-production, quality improvement, patient experience, system-redesign

\section{Introduction}

Since its adoption by the United Kingdom's National Health Service (NHS) for quality improvement in 2006, experience-based co-design (EBCD) improvement initiatives have steadily increased. ${ }^{1}$ This has been accompanied by a notable trend toward participation of service users (a term encompassing patients, consumers, clients and generally indicating an engagement with health services), carers and health professionals in healthcare

Patient Experience Journal, Volume 6, Issue 2 - 2019

(C) The Author(s), 2019. Published in association with The Beryl Institute and Patient Experience Institute

Downloaded from www.pxjournal.org 
improvement and systems re-design efforts using coproduction methods of which EBCD is one variant. ${ }^{2}$ This participatory trend to co-production and co-design in quality improvement has been referred to as the Participatory Zeitgeist - the spirit of our times. ${ }^{3}$ The trend is configured within political, cultural and social processes of change all directed toward greater participation of people with lived-experience in healthcare design, planning, re-design and improvement processes. ${ }^{4}$ The participatory push sees greater recognition of the importance of patient experience as a driver for healthcare improvement and service users working as partners in change, but it has not come without debate, challenges and conceptual confusion. ${ }^{5}$

EBCD is an approach used within healthcare improvement that has a clearly articulated and staged process, yet it is implemented variably. Participatory and narrative methods are employed to develop a deep understanding the experiences of care (both in terms of receipt and delivery of services), followed by the use of design methods and learning theory for service users and health professionals to co-design improvements collaboratively and implement the changes. ${ }^{6,7}$ EBCD is based on the premise that co-design offers the potential for treatment and care to be experience-focused rather than just protocol driven. ${ }^{8}$ Experience can be defined as the 'sum of all interactions shared by an organisation's culture that include patient perceptions across the continuum of care.' There is emerging evidence that indicates better patient experience may be associated with improved outcomes in clinical effectiveness and safety. ${ }^{?}$ Similarly positive effects have been shown from interventions of person centred care in terms of self-rated health, well-being, quality of care, satisfaction and in a small number of studies health measures for diabetes such as HbA1c, Body Mass Index (BMI), costs and reduced length of hospital stay. ${ }^{10}$ Systematic reviews indicate that more stringent studies are required however to determine the evidence base.$^{10}$

Internationally, toolkits exist that offer step-by-step guidance with case studies and resources to support the implementation of EBCD for quality improvement. The Point of Care Foundation hosts the original EBCD: experience-based co-design toolkit that emerged from a collaboration with King's College London, National Health Service (NHS) Foundation Trusts and The King's Fund. ${ }^{11,} 12$ The Waitemata District Health Board in New Zealand provides a Health Service Co-Design toolkit. ${ }^{13}$ More recently, the Australian Hospitals and Healthcare Associations (AHHA) with the Consumers Health Forum (CHF) launched an Australian toolkit. ${ }^{14}$

Despite these available toolkits and published guidance, there appears to be considerable variation in EBCD implementation, ongoing challenges for equitable participation and there is a limited evidence base in terms of the sustained impacts of implemented improvements and if health outcomes should result. ${ }^{15-18}$ The evidence for whether EBCD leads to improved health outcomes, clinical effectiveness and safety remains limited despite some 60 or more projects that have used the approach for quality improvement. ${ }^{19}$ Literature is also emerging around the need for tailored or distinctive EBCD approaches in populations where vulnerabilities, marginalisation and experiences of care may have been extremely disempowering. ${ }^{17}$

In one part the variability in the implementation of EBCD might be explained and be seen to be necessary by the range of participatory and narrative methods that can be used to develop deep understanding of service user experiences. Variability can also emerge in the diversity of design thinking and learning theories that can inform codesign processes. Stories can be identified and shared using emotion mapping, experience videos (also termed trigger films), other narrative or visual communication forms such as personas, journeys and storyboarding and to a lesser extent experience data collected from purpose designed apps. ${ }^{20}$ Irrespective of what narrative method is drawn upon, the intention of sharing service user and health professional experiences is to develop an understanding of the experiential touch points (both positive and negative) and to identify areas for change. Moreover, what is critical to this stage is to build shared understanding to foster a space of where empathy between service users and health professionals might be made possible. The extent to which shared understanding and empathy is associated with successful co-design, improvement implementation and outcomes of EBCD has not, to our knowledge, been evaluated beyond interview data.

If the gathering of experiences is already diverse, variation in the implementation of EBCD emerges again in codesign processes in terms of (1) who facilitates groups and the skills that may be required, (2) how well all participants are prepared for co-design (not only improvement leads), (3) if, when and how external designers are engaged ${ }^{21}$, (4) what rationale is provided for design techniques and tools selected to co-design solutions or improvements, (5) what strategies are employed to implement changes, and, (6) how organisational and individual improvements are measured. ${ }^{22}$

While flexibility can be considered a strength of EBCD, it appears to bring challenges for consistency across EBCD implementation in quality improvement projects. This makes it difficult to determine the components that are required for success and raises questions around translation of the approach across healthcare settings. In Australia, the New South Wales (NSW) Ministry of Health has progressively invested in several projects to 
position EBCD as an essential quality improvement approach. The first attempt of this was the implementation of EBCD in NSW Emergency Departments and associated departments of seven public hospitals in 2007. ${ }^{23-26}$ In 2015, the Agency for Clinical Innovation (ACI), a NSW Ministry of Health pillar organisation made a strategic decision to further explore the feasibility of EBCD as a quality improvement approach. The decision was based on meeting Australian National Safety and Quality Health Service participation standards to value lived-experience, engage service users in re-design processes and the emerging promise of EBCD. ${ }^{27}$ As part of this six EBCD projects were conducted in adult mental health, rehabilitation, blood and bone marrow transplant, brain injury rehabilitation, urinary incontinence and intellectual disability settings between 2015-2018.

In 2018, we conducted a case study synthesis of the projects to identify the challenges of participation in, and implementation of EBCD to identify lessons for future improvement projects. The EBCD project approaches and the synthesis methods are explained below, and the results follow.

\section{Methods}

The six EBCD projects were conducted between December 2015 and December 2018 in mental health, rehabilitation, blood and bone marrow transplant, brain injury rehabilitation, urinary incontinence and intellectual disability across metropolitan, regional and rural health care settings in NSW, Australia. Each was overseen by a project team, which included project leads, health professionals and service users. Each project employed the EBCD cycle as shown in Figure 1: engage, gather, understand, improve and measure.

Leading up to commencement of the six EBCD projects, ACI contracted LM for 12 months to provide a masterclass, a full day facilitated project establishment workshop for project teams and bi-monthly coaching sessions ( 2 hours each), which included follow-up phone and email support for project leads. LM was available to the project teams but did not take part in the implementation of EBCD projects on the ground. The content of this training and coaching is summarised in Table 1, which followed the EBCD cycle as described in Figure 1.

Figure 1. Experience-based co-design process

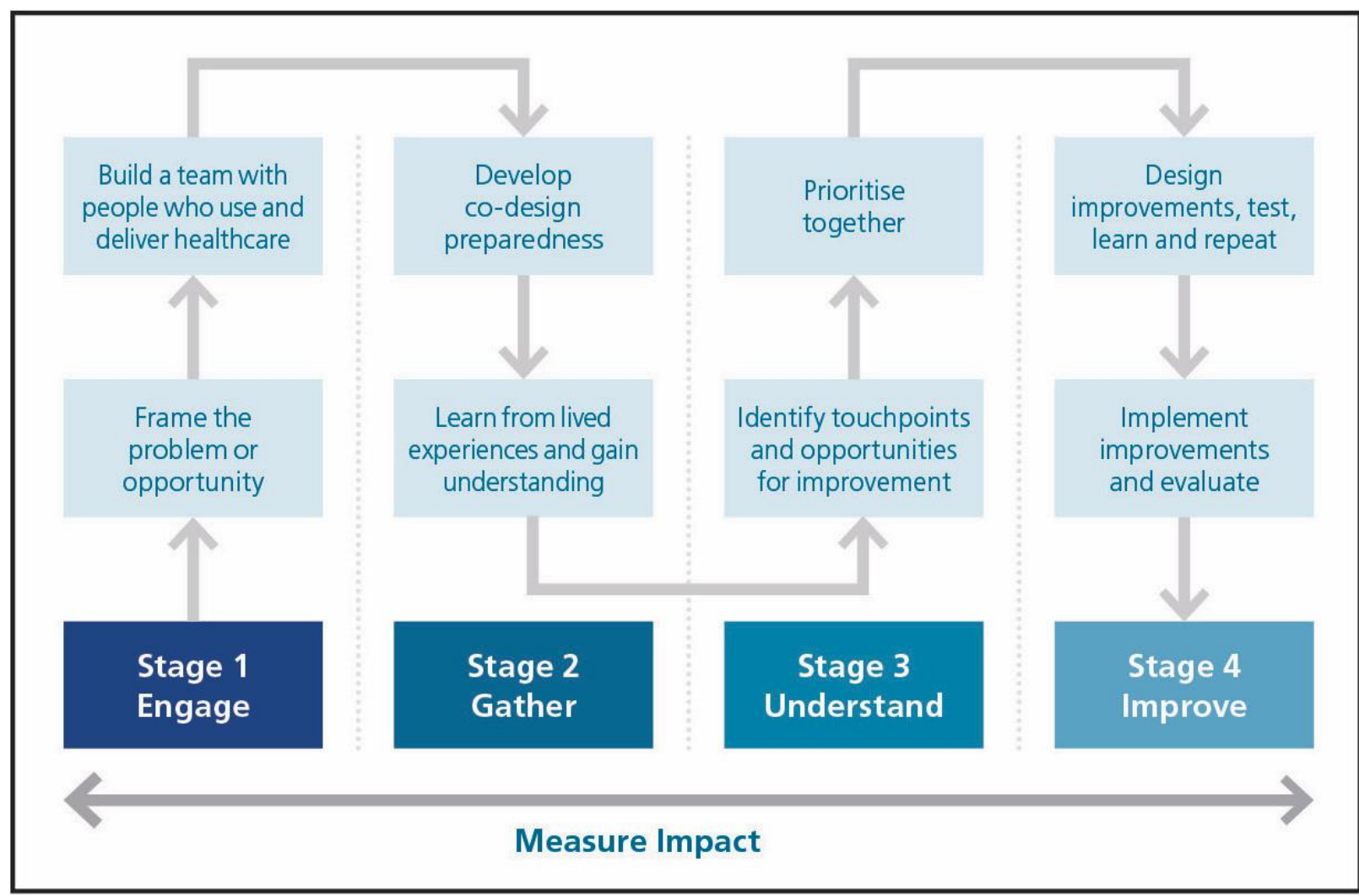


On conclusion of the EBCD projects, five reflexive workshops (4 hrs each) were facilitated by VP to document the EBCD processes, methods and identify themes across the cases related to participation and implementation. This involved a case to case synthesis using a variable-oriented approach. ${ }^{28}$ In this approach particular themes were identified within workshops and then compared across cases. Following this, those themes were synthesised and considered within an overarching thematic that workshop participants determined had affected implementation and participation in EBCD across all six projects. This thematic related to co-design preparedness and capability development. To explore this thematic and the need for preparedness the team used a previously developed explanatory theoretical model (ETM) of change for co-design and co-production in healthcare improvement to develop a suggested model of capability and preparedness for future use. ${ }^{3}$ This model utilises eight mechanisms described within the ETM: recognition, dialogue, cooperation, accountability, mobilisation, creativity, enactment, attainment ${ }^{3}$ to guide what needs to be attended to in preparedness and capability development. Importantly the mechanisms are situated within ideal relational transitions that are dependent upon the conditions and processes being generated. This analysis is focused on the mechanisms only.

\section{Results}

Tables 1, 2 and 3 (See Appendix) illustrate the documentation of the methods used for gathering experiences in the six projects, the touch points that emerged, and the co-designed improvements including how these were developed across each EBCD project. All six projects had service user and health professional involvement on a project management and governance level, but this varied on the ground as shown in Table 2. More than 355 experiences were shared across the projects making it difficult to identify key areas for change and to focus on improvements over experience.

Themes that were identified from the co-design stage included the challenges of resourcing people to attend codesign; questions of representativeness within co-design of people with lived-experience; the importance of livedexperience voices; how to engage people on the fringes; balancing the focus on experience with improvement; variability in the tools and techniques used to co-design improvements, the development of strategies for implementation; and moving health professionals out of traditional ways of working and mindsets.

The synthesis of these themes within the overarching thematic of preparedness and capability development lead us to think about the organisation of capability and preparedness in terms of ways of being, knowing and
Figure 2. Experience-based co-design capability model

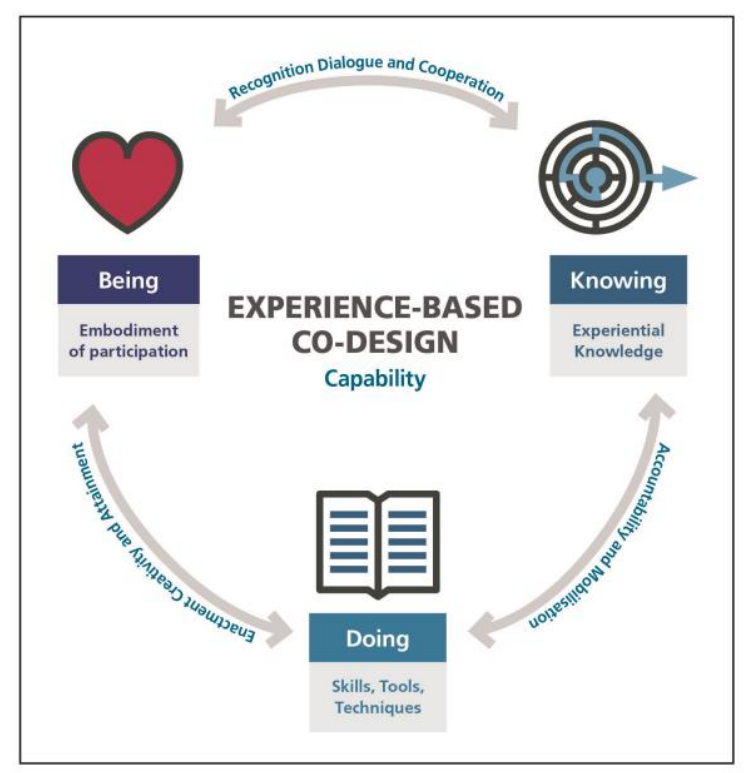

doing. We considered what work would be needed in these three areas to generate the conditions and processes of the eight mechanisms of change for co-design and coproduction. Figure 2 highlights the relationship of the mechanisms and areas for preparedness, followed by a description of what needs to be attended to, to build capabilities.

\section{Ways of being-embodying a cooperative mindset to be accountable for participation}

A common theme for all six projects was the tension that surfaced when health professionals and service users came together to work collaboratively and were required to move out of traditional ways of working and mindsets. Although project teams co-produced a set of principles as shown in Table 5 to guide collaboration and underpin the EBCD process, the principles were not enacted fully. Collaboration was made difficult and at times was hindered because values, attitudes and perspectives about working together had not been shifted prior to joining together in the co-design stage. Although most health professionals instinctively accepted EBCD as a collaborative approach and valued lived-experience and working together, the transition away from more traditional and evidence-based quality improvement methodologies and power structures remained difficult. In this regard the health professionals did not fully embrace the EBCD approach.

These tensions signalled the importance of preparedness work needing to bring a cooperative mindset and spirit of participation into 'being'. Such a focus is more than skills and techniques, it is about the importance of recognising 
lived-experience and expert knowledge within processes. It is deeply connected with questions of identity and values. Preparedness therefore needs to work specifically on relational and attitudinal shifts in participants that can lead to a participatory and collaborative culture. This means having explicit dialogue and activities within preparedness phases that attend to the need to shift the health paradigm where the balance of power often sits with health professionals. It also requires ways to foster recognition of lived-experience knowledge as valued and therefore equal to other kinds of knowledge. For all six projects, transferring and sharing power was difficult and for the most part remained unsuccessful. This was perpetuated by existing vertical decision-making processes for approval and the allocation of resources, traditional power relations and professional hierarchies.

Therefore, in ways of being, the capability development needs to explicitly work to address power, values and relational dynamics prior to undertaking EBCD processes. This can enable insights into contextual and environmental factors that may enable or hinder EBCD, including organisational readiness and culture, previous experience and success in collaborating with service users and dedicated resources. Specific preparedness activities will be required with participants rather than relying on intrinsic motivations, which is notably different between health professionals and service users. Findings approaches that can identify and address biases ahead of time will provide greater opportunities for the cooperative spirit to emerge.

\section{Knowing about co-design - embracing lived- experience knowledge to mobilise and enact change}

If being, signals the importance of capabilities around a participatory mindset and cooperative identity, then, knowing is about bringing this knowledge together to enact change. Bringing co-design into being also requires knowledge enhancement of approach and processes for service users and health professionals. It also means taking time to get to know each other in the room for co-design. The bi-monthly coaching sessions enabled service users and health professionals leading EBCD projects to build their capability and experience in applying the approach over a 12-month timeframe. The coaching also fostered open communication between EBCD leads and provided a space to share learning and resources. The six projects struggled however to successfully recognise and develop the capabilities of frontline health professionals and other service users within workshops to undertake co-design.

Knowing about co-design skills and the intricacies of the approach is important as it can be used as a tool to address the disinvestment that can often occur on completion of the gathering stages of the EBCD process (Figure 1). Ensuring there is clarity around co-design processes upfront builds shared expectation that enables people to feel a sense of accountability for change and to mobilise around this. This includes valuing and preferencing lived experiences of services as expert kinds of knowledge from the basis of which to co-develop solutions and improvements.

In the six projects the model used to build EBCD preparedness may have fallen short as the development of capabilities were not applied consistently for all service users, health professionals and sponsor groups. For example, across all six projects only one of the sponsors had a thorough understanding of EBCD, and practical experience in using the approach. Service users and health professionals who dipped in and out of the EBCD process found it difficult to grasp and enact the approach in an authentic and consistent way; indicating that preparedness needs to concentrate on the importance of sustained commitment to the process. While health professionals and service users could access the coaching sessions remotely, participation in these was not consistent. Finding a suitable time for the coaching sessions was difficult with many service users and health professionals being unable to pre-allocate the time or were often unavailable because of competing priorities.

Health professionals and sponsors who joined the projects after commencement did not always access orientation to EBCD either and there may have been inconsistencies in the understanding of the approach as a result. This limited understanding of approach may have lead health professionals and sponsors to lean back on the traditional ways of doing improvement and led to reinforcement of existing divisions and power imbalances. This points to the importance of continuity of participants within EBCD as an improvement method.

Another challenge experienced by most of the EBCD projects, was a lack of follow through with collaborative change processes to identify and co-design improvements. This may have been caused by the initial EBCD training for project leads being heavily weighted to experiences stages of the process (Figure 1) and not focused on the skills and techniques for co-design or the development of strategies for implementation of improvements. While the initial set up of the project teams included an implementation lead, for most projects the team configuration had changed by the time the project reached the 'test and implement' stage of the EBCD process (Figure 1). For some projects the allocation of an implementation lead was time-limited and often delays in the project resulted in implementation support in this capacity being unavailable in the latter stages of the process.

Preparedness for co-design therefore needs to include recognition and dialogue around lived-experience and for some groups building in flexibility in participation; the case 
synthesis indicates that to date flexibility has resulted in continuity challenges within the improvement method and is an area for consideration. For some service users the flare-ups of their health condition impacted on their capacity to participate in EBCD processes over a long period of time. Similarly, competing demands on time further signalled the importance of having ongoing capability development opportunities that are adaptable to meet the needs and preferences of service users and health professionals.

\section{Doing co-design creatively to attain improvements long term}

The kinds of capabilities discussed so far refer quite specifically to the importance of values and principles that operate to invoke participatory mindsets, cooperative identities and a recognition that different forms of knowledge count equally to other kinds. These elements need to come together in the doing of co-design and techniques to evoke co-developed improvements. In ways of doing there is a need to purposively match the techniques and tools required to support creativity and attain co-designed solutions. Such matching of co-design techniques and tools needs to also lead to implementation of improvements.

Design techniques and tools such as generating problem frames, journey mapping and testing ideas through storyboards and iterative prototyping were used as part of the co-design process in the six projects (Table 2). However, some of the tools and techniques brought into the EBCD process were unfamiliar to service users and health professionals at the start. This signalled the importance of covering the what, why and how of different design techniques and tools and their application to the co-design process for all participants ahead of the doing of co-design.

At times the 'messiness' of design and the increased time in the problem space before transitioning to solutions and improvements was challenging across a number of the projects. It became more challenging when external designers were engaged after completion of the gather and understand stages of the EBCD process (Figure 1). The external designers had expertise in human-centred design and were not part of the initial project teams or from the health system. The tendency for the external designers to push the project back into the earlier stages of experience once again caused initial tensions and delays within the project and led to frustrations of staying in experiences that some people felt they had already shared. However, the use of external designers also resulted in more innovative design solutions and increased design capabilities for health professionals and service users. The projects were not able to explore the extent to which this led to greater or lesser implementation of the changes, but this should be an area for focus in future EBCD projects for healthcare improvement. The ideal would be that designers will also be a part of the preparedness phases so that tensions might be minimised and everyone can develop an understanding of the techniques being enacted for the co-development of improvements.

\section{Discussion}

Participation and involvement with service users in healthcare systems planning, quality improvement and redesign, and evaluation is increasingly becoming core business for governments and healthcare improvement organisations internationally. This case synthesis has highlighted that participation with service users and health professionals faces a critical challenge to ensure that codesign efforts not only lead to clear improvements but that these are subsequently implemented. Further development of the means to assess and measure the processes and results of these co-design efforts is a next important step in the EBCD field. ${ }^{29}$

To date, published evaluations point to some of the reasons as to why variability in implementation of EBCD method, implementation of improvements and challenges of measurement persist in EBCD projects, but we lack critical evidence about which component parts are essential to success. There is also minimal attention and literature that has evaluated the direct links between EBCD improvement and the goal of healthcare improvement - improved patient experiences and health outcomes. 22,29

The case synthesis findings indicate that further efforts in preparedness phases of EBCD that foster ways of being (a participatory mindset and spirit-or, in short, a collective identity) and ways of knowing (acknowledging the importance of lived-experience knowledge and skills to develop co-design capacity) is a critical step to improve this (Table 6, See Appendix). Currently the training or orientation procedures (preparedness) that have been used in EBCD studies are minimally described and lack information about the kinds of capabilities and capacities we must revise in the design spiral. The tendency is to fall into a trap noted recently by Beresford as being unidimensional, reductionist and not addressing power differences in ways that address the ambiguities and complexities of involvement. ${ }^{4}$

Developing EBCD ways of being and knowing means finding concrete ways forward to establish power sharing, ensure representation of people with lived experiences is occurring beyond tokenistic involvement, and the utilisation of strategies to mobilise the implementation of changes. Better attention to these realities within preparedness phases and alignment with the recently identified mechanisms of change for co-design and 
coproduction outlined in an explanatory theoretical model would enhance the field and possibly result in some of the transformations we seek for greater implementation of changes. There must also be some measures to counter the risks of getting on the EBCD bandwagon in improvement where we see little change implemented and sustained. Our view is that not providing full capability development to all participants including health professionals and service users, increases this risk.

Ways of being, knowing and doing are interdependently important for developing the capabilities to use EBCD processes, and improve experiences, and ideally outcomes. Utilising eight mechanisms identified within an ETM of change as guidance for what is critical in co-design preparedness can offer a pathway forward in the development of required capabilities and be applied across healthcare settings. The long-term impact and sustainability of EBCD as a quality improvement approach depends both on its effectiveness in the "real world" including how widely and easily it can be implemented and also on how it can lead to sustained quality improvement.

\section{References}

1. Robert G, Cornwell J. Rethinking policy approaches to measuring and improving patient experience. . Journal of Health Services Research \& Policy. 2013;18(2):67-9.

2. Jo S, Nabatchi T. Coproducing healthcare: individuallevel impacts of engaging citizens to develop recommendations for reducing diagnostic error. Public Management Review. 2019;21(3):354-75.

3. Palmer VJ, Weavell W, Callander R, Piper D, Richard L, Maher L, et al. The Participatory Zeitgeist: an explanatory theoretical model of change in an era of coproduction and codesign in healthcare improvement. Medical Humanities. 2018.

4. Beresford P. Public Participation in Health and Social Care: Exploring the Co-production of Knowledge. Frontiers in Sociology. 2019;3(41).

5. Oliver K, Kothari A, Mays N. The dark side of coproduction: do the costs outweigh the benefits for health research? Health Research Policy and Systems. 2019;17(1):33.

6. Bate P, Robert G. Bringing User Experience to Healthcare Improvement: The Concepts, Methods and Practices of Experience-based Design. Oxford: Radcliffe; 2007.224 p.

7. Iedema R, Merrick E, Piper D, Britton K, Gray J, Verma R, et al. Codesigning as a Discursive Practice in Emergency Health Services: The Architecture of Deliberation. The Journal of Applied Behavioral Science. 2010;46(1):73-91.

8. Foundation. PoC. Experience-based Co-design toolkit England: Point of Care Foundation; 2018 [Available from: https://www.pointofcarefoundation.org.uk/resource/ experience-based-co-design-ebcd-toolkit/

9. Doyle C, Lennox L, Bell D. A systematic review of evidence on the links between patient experience and clinical safety and effectiveness. BMJ Open. 2013;3(1).

10. Olsson L-E, Jakobsson Ung E, Swedberg K, Ekman I. Efficacy of person-centred care as an intervention in controlled trials - a systematic review. Journal of Clinical Nursing. 2013;22(3-4):456-65.

11. NHS Institute for Innovation \& Improvement. Method, toolkit and DVD 'how to' use EBCD. Coventry: NHS Institute for Innovation \& Improvement; 2011.

12. The King's Fund. Experience Based Co-Design Toolkit. London, UK: The King's Fund; 2013.

13. Boyd H, McKernon S, Old A. Health service co-design toolkit. Takapuna, NZ: Waitemata Distrct Health Board; 2010.

14. Dawda P, Knight A. Experience-based co-design toolkit: a toolkit for Australia Australia: Australian Healthcare and Hospitals Assocation; 2017 [Available from: https://ahha.asn.au/experience-based-co-designtoolkit.

15. Blinded. BMJ Open. 2015;5(3):e006688.

16. Donetto S, Tsianakas V, Robert G. Using Experiencebased Co-design (EBCD) to improve the quality of healthcare: mapping where we are now and establishing future directions. London: King's College London; 2014.

17. Mulvale G, Moll S, Miatello A, Robert G, Larkin M, Palmer V, J., et al. Codesigning health and other public services with vulnerable and disadvantaged populations: Insights from an international collaboration. Health Expectations. 2019;0(0).

18. Blinded. The Journal of Health Design. 2018;3(1).

19. Palmer VJ, Chondros P, Piper D, Callander R, Weavell W, Godbee K, et al. The CORE study protocol: a stepped wedge cluster randomised controlled trial to test a co-design technique to optimise psychosocial recovery outcomes for people affected by mental illness in the community mental health setting. BMJ Open. 2015;5(e006688).

20. Hackett CL, Mulvale G, Miatello A. Co-designing for quality: Creating a user-driven tool to improve quality in youth mental health services. Health expectations : an international journal of public participation in health care and health policy. 2018;21(6):1013-23.

21. Robert G, Macdonald AS. Co-design, organizational creativity and quality improvement in the healthcare sector: 'designerly' or 'design-like’? In: Sangiorgi D, Prendiville A, editors. Designing for Service: Key Issues and New Directions. London: Bloomsbury; 2017. p. 117.

22. Larkin M, Boden ZVR, Newton E. On the Brink of Genuinely Collaborative Care:Experience-Based CoDesign in Mental Health. Qualitative Health Research. 2015;25(11):1463-76. 
23. Iedema R, Merrick E, Piper D, Walsh J. Emergency department co-design stage 1 evaluation-report to health services performance improvement branch, NSW Health, Centre for Health Communication. University of Technology, Sydney. 2008.

24. Piper D, Iedema R, Gray J, Verma R, Holmes L, Manning N. Utilizing experience-based co-design to improve the experience of patients accessing emergency departments in New South Wales public hospitals: an evaluation study. Health Services Management Research. 2012;25(4):162-72.

25. Piper D, Iedema R, Merrick E. Emergency department co-design program 1 stage 2 evaluation report-final report to health services performance improvement branch, NSW Health. Sydney: Centre for Health Communication, University of Technology Sydney; 2010.
26. Piper D, Iedema R, Merrick E, Perrott B. Experiencebased Co-Design Program 2 Stage 1 Evaluation Report-final report to health services performance improvement branch, NSW Health. Sydney: Centre for Health Communication, University of Technology Sydney; 2010.

27. ACSQH. National Standards for Consumers and Carers. In: Healthcare ACoSaQi, editor. Canberra: Department of Health; 2017.

28. Yore L, Rossman G. Case to Case Synthesis. In: Mills A, Durepos G, Wiebe E, editors. Encyclopedia of Case Study Research. Thousand Oaks: SAGE Publishers; 2012. p. 130-4.

29. Batalden P. Getting more health from healthcare: quality improvement must acknowledge patient coproduction — an essay by Paul Batalden. BMJ. 2018;362:k3617.

\section{Appendix}

Table 1. Masterclass and coaching capabilities for project leads

\begin{tabular}{|l|l|l|}
\hline $\begin{array}{l}\text { EVIDENCE } \\
\text { Understand the context, principles, } \\
\text { evidence and imperative for working } \\
\text { closely with service users and health } \\
\text { professionals to co-design healthcare } \\
\text { services }\end{array}$ & $\begin{array}{l}\text { PLAN AND DELIVER } \\
\text { Understand how to plan and } \\
\text { deliver an EBCD project for } \\
\text { effective sustainability }\end{array}$ & $\begin{array}{l}\text { GATHER THE EXPERIENCE } \\
\text { Understand and systematically use a } \\
\text { range of tools and techniques to } \\
\text { gather lived experiences through } \\
\text { narrative and stories }\end{array}$ \\
$\begin{array}{l}\text { UNDERSTAND THE } \\
\text { EXPERIENCE } \\
\begin{array}{l}\text { Comprehend and use key techniques } \\
\text { to understand the experiences of } \\
\text { healthcare and organise themes for } \\
\text { improvement }\end{array}\end{array}$ & $\begin{array}{l}\text { IMPROVE THE } \\
\text { EXPERIENCE } \\
\text { service users, health } \\
\text { professionals, and other } \\
\text { stakeholders to turn experience } \\
\text { into action through co-design to } \\
\text { achieve improvement and } \\
\text { innovation in healthcare }\end{array}$ & $\begin{array}{l}\text { MEASURE FOR } \\
\text { IMPROVEMENT } \\
\text { Understand how to measure for } \\
\text { improvement }\end{array}$ \\
\end{tabular}


Table 2. Overview of the six experience-based co-design projects

\begin{tabular}{|c|c|c|c|c|c|}
\hline \multirow[t]{2}{*}{ Setting } & \multirow{2}{*}{$\begin{array}{l}\text { Duration of } \\
\text { EBCD } \\
\text { project cycle }\end{array}$} & \multirow{2}{*}{$\begin{array}{l}\text { Contextual and } \\
\text { Environmental } \\
\text { Factors }\end{array}$} & \multicolumn{3}{|c|}{ EBCD Stages: techniques and tools used for each stage } \\
\hline & & & Gather & Understand & Improve \\
\hline $\begin{array}{l}\text { Day } \\
\text { Rehabilitation } \\
\text { Services } \\
\text { (Regional Sub- } \\
\text { Acute) }\end{array}$ & 20 months & $\begin{array}{l}\text { Intensive ambulatory } \\
\text { program for service } \\
\text { users who can safely } \\
\text { remain at home } \\
\text { while they continue } \\
\text { to work towards } \\
\text { their rehabilitation } \\
\text { goals. }\end{array}$ & $\begin{array}{l}\text { Surveys: service users } \\
(\mathrm{n}=90) \text {, service users } \\
\text { with carer support } \\
(\mathrm{n}=17) \text {, carers }(\mathrm{n}=14) \\
\text { Focus Groups: health } \\
\text { professionals x } 1 \\
(\mathrm{n}=13) \\
\text { Interviews: service } \\
\text { users with carer } \\
\text { support }(\mathrm{n}=5)\end{array}$ & $\begin{array}{l}\text { Thematic analysis } \\
\text { of surveys, } \\
\text { interviews to } \\
\text { create an } \\
\text { experience map } \\
\text { and identify touch } \\
\text { points }\end{array}$ & $\begin{array}{l}\text { Prioritisation of } \\
\text { touch points, } \\
\text { ideation, } \\
\text { prototyping, } \\
\text { workshops/co- } \\
\text { design sessions, } \\
\text { affinity mapping }\end{array}$ \\
\hline $\begin{array}{l}\text { Adult Community } \\
\text { Mental Health } \\
\text { Services } \\
\text { (Rural) }\end{array}$ & 18 months & $\begin{array}{l}\text { Support for } \\
\text { recovery-oriented } \\
\text { community care }\end{array}$ & $\begin{array}{l}\text { Focus groups: service } \\
\text { users x } 4(\mathrm{n}=27) \text {, } \\
\text { families x } 3(\mathrm{n}=20) \text {; } \\
\text { health professionals } \\
\text { x } 6(\mathrm{n}=52) \\
\text { Experience } \\
\text { questionnaires: } \\
\text { service users }(\mathrm{n}=14)\end{array}$ & $\begin{array}{l}\text { Thematic analysis } \\
\text { Touch points }\end{array}$ & $\begin{array}{l}\text { Prototyping, } \\
\text { workshops/co- } \\
\text { design sessions }\end{array}$ \\
\hline $\begin{array}{l}\text { Brain Injury } \\
\text { Rehabilitation } \\
\text { (Sub-acute } \\
\text { metropolitan, } \\
\text { rural and } \\
\text { regional) }\end{array}$ & 30 months & $\begin{array}{l}\text { Age range } 15 \text { years } \\
\text { to } 67 \text { years } \\
\text { Acute phase of care } \\
\text { through to active } \\
\text { and community } \\
\text { rehabilitation and } \\
\text { long term } \\
\text { community team } \\
\text { management. }\end{array}$ & $\begin{array}{l}\text { Interviews using } \\
\text { structured personas: } \\
\text { service users }(n=22) \\
\text { Focus groups: service } \\
\text { users }(n=20)\end{array}$ & $\begin{array}{l}\text { Thematic analysis } \\
\text { Touch points }\end{array}$ & $\begin{array}{l}\text { Prioritisation, } \\
\text { ideation, scenarios, } \\
\text { prototyping, } \\
\text { personas, } \\
\text { workshops and co- } \\
\text { design sessions, co- } \\
\text { design teams, } \\
\text { affinity mapping }\end{array}$ \\
\hline $\begin{array}{l}\text { Young People } \\
\text { with Urinary } \\
\text { Incontinence } \\
\text { (Metropolitan, } \\
\text { rural and } \\
\text { regional) }\end{array}$ & $\begin{array}{l}24 \text { months - } \\
\text { current }\end{array}$ & $\begin{array}{l}\text { Only one } \\
\text { incontinence clinic } \\
\text { at the time in NSW. }\end{array}$ & $\begin{array}{l}\text { Interviews: service } \\
\text { users }(\mathrm{n}=5) \text {, parents } \\
(\mathrm{n}=9), \text { health } \\
\text { professionals } \mathrm{n}=12) \\
\text { Observation: one } \\
\text { occasion at one clinic } \\
\text { for } 60 \text { minutes }\end{array}$ & $\begin{array}{l}\text { Thematic analysis } \\
\text { Experience map } \\
\text { Touch points }\end{array}$ & $\begin{array}{l}\text { Prioritisation, } \\
\text { ideation, scenarios, } \\
\text { storyboards, } \\
\text { prototyping, } \\
\text { personas, } \\
\text { workshops/co- } \\
\text { design sessions, } \\
\text { affinity mapping }\end{array}$ \\
\hline $\begin{array}{l}\text { Blood \& Marrow } \\
\text { Transplant Long } \\
\text { Term Follow Up } \\
\text { (Metropolitan and } \\
\text { Rural) }\end{array}$ & $\begin{array}{l}24 \text { months - } \\
\text { current }\end{array}$ & $\begin{array}{l}7 \text { allogeneic } \\
\text { transplant facilities } \\
\text { in NSW ( } 5 \text { adult and } \\
2 \text { paediatric); } \\
\text { approximately } 200 \\
\text { transplants are } \\
\text { performed each year. }\end{array}$ & $\begin{array}{l}\text { Interviews: service } \\
\text { users }(\mathrm{n}=8) \\
\text { Focus groups: health } \\
\text { professionals x } 3(1 \\
\text { paediatric, } 2 \text { adult) } \\
(\mathrm{n}=16)\end{array}$ & $\begin{array}{l}\text { Thematic analysis } \\
\text { Experience map } \\
\text { Touch points }\end{array}$ & $\begin{array}{l}\text { Prioritisation, } \\
\text { ideation, } \\
\text { workshop/co- } \\
\text { design sessions, } \\
\text { affinity mapping }\end{array}$ \\
\hline $\begin{array}{l}\text { Hospitalisation of } \\
\text { People with } \\
\text { Intellectual } \\
\text { Disability } \\
\text { (Metropolitan) }\end{array}$ & 18 months & & $\begin{array}{l}\text { Interviews: service } \\
\text { users with carer } \\
\text { support }(\mathrm{n}=1) \text {, carers } \\
(\mathrm{n}=3), \text { health } \\
\text { professionals }(\mathrm{n}=1) \\
\text { Focus groups: health } \\
\text { professionals x } 1 \\
(\mathrm{n}=6)\end{array}$ & $\begin{array}{l}\text { Thematic analysis } \\
\text { Experience map } \\
\text { Touch points }\end{array}$ & $\begin{array}{l}\text { Prioritisation, } \\
\text { ideation, } \\
\text { workshops/ co- } \\
\text { design sessions, co- } \\
\text { design teams, } \\
\text { affinity mapping } \\
\text { and quality } \\
\text { improvement } \\
\text { methods }\end{array}$ \\
\hline
\end{tabular}


Table 3. Co-design techniques and tools used in the six experience-based co-design projects

\begin{tabular}{|c|c|c|c|c|c|c|}
\hline $\begin{array}{l}\text { Technique / Tool } \\
\text { used in the co- } \\
\text { design process }\end{array}$ & $\begin{array}{l}\text { Blood \& } \\
\text { Marrow } \\
\text { Transplant } \\
\text { Long Term } \\
\text { Follow Up }\end{array}$ & $\begin{array}{l}\text { Young People } \\
\text { with Urinary } \\
\text { Incontinence }\end{array}$ & $\begin{array}{l}\text { Day } \\
\text { Rehabilitation } \\
\text { Services }\end{array}$ & $\begin{array}{l}\text { Adult } \\
\text { Community } \\
\text { Mental } \\
\text { Health } \\
\text { Services }\end{array}$ & $\begin{array}{l}\text { Brain Injury } \\
\text { Rehabilitation }\end{array}$ & $\begin{array}{l}\text { Hospitalisation } \\
\text { of People with } \\
\text { Intellectual } \\
\text { Disability }\end{array}$ \\
\hline $\begin{array}{l}\text { Ideation } \\
\text { Structured approach } \\
\text { to generate ideas or } \\
\text { solutions }\end{array}$ & 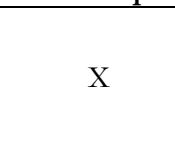 & $\mathrm{X}$ & $\mathrm{X}$ & & $\mathrm{X}$ & $\mathrm{X}$ \\
\hline $\begin{array}{l}\text { Prioritisation } \\
\text { Ranking or voting to } \\
\text { help stakeholders } \\
\text { agree on ideas and } \\
\text { priorities }\end{array}$ & $\mathrm{X}$ & $\mathrm{X}$ & $\mathrm{X}$ & & $\mathrm{X}$ & $\mathrm{X}$ \\
\hline $\begin{array}{l}\text { Scenario } \\
\text { Sequence of events } \\
\text { illustrating the } \\
\text { activities of one or } \\
\text { more users in a real- } \\
\text { world setting }\end{array}$ & & $\mathrm{X}$ & & & $\mathrm{X}$ & $\mathrm{X}$ \\
\hline $\begin{array}{l}\text { Prototype } \\
\text { Basic version of a } \\
\text { proposed solution, } \\
\text { enabling testing with } \\
\text { users and other } \\
\text { stakeholders }\end{array}$ & & $\mathrm{X}$ & $\mathrm{X}$ & $\mathrm{X}$ & $x$ & \\
\hline $\begin{array}{l}\text { Personas } \\
\text { Characters created } \\
\text { using data collected } \\
\text { from experiences of } \\
\text { real people }\end{array}$ & & $\mathrm{X}$ & & & $\mathrm{X}$ & \\
\hline $\begin{array}{l}\text { Storyboards } \\
\text { Visual representation } \\
\text { of an idea or } \\
\text { prototype, enabling } \\
\text { testing with users and } \\
\text { other stakeholders }\end{array}$ & & $\mathrm{X}$ & & & & \\
\hline $\begin{array}{l}\text { Workshops / Co- } \\
\text { design Sessions } \\
\text { Dialogue between } \\
\text { stakeholders to } \\
\text { gather insights, ideas } \\
\text { and set priorities }\end{array}$ & $\mathrm{X}$ & $\mathrm{X}$ & $\mathrm{X}$ & $\mathrm{X}$ & $\mathrm{X}$ & $x$ \\
\hline $\begin{array}{l}\text { Co-design Teams } \\
\text { Small groups } \\
\text { designing and } \\
\text { implementing } \\
\text { improvements }\end{array}$ & & & & & $\mathrm{X}$ & $\mathrm{X}$ \\
\hline $\begin{array}{l}\text { Affinity mapping } \\
\text { Grouping and } \\
\text { organisation of ideas, } \\
\text { opportunities and } \\
\text { areas for } \\
\text { improvement }\end{array}$ & $\mathrm{X}$ & $\mathrm{X}$ & $\mathrm{X}$ & & $\mathrm{X}$ & $\mathrm{X}$ \\
\hline $\begin{array}{l}\text { Other Quality } \\
\text { improvement } \\
\text { methods }\end{array}$ & & & & & & $\mathrm{X}$ \\
\hline
\end{tabular}


Table 4. Summary of improvements for six experience-based co-design projects

\begin{tabular}{|c|c|c|c|}
\hline \multirow[t]{2}{*}{ Setting } & \multicolumn{3}{|l|}{ Improvements } \\
\hline & Identified improvements, or, touchpoints & Co-designed solutions & Implemented solutions \\
\hline $\begin{array}{l}\text { Day } \\
\text { Rehabilitation } \\
\text { Services } \\
\text { (Regional Sub- } \\
\text { Acute) }\end{array}$ & $\begin{array}{l}\text { - Service promotion information } \\
\text { - Sharing results and clinical information with patients } \\
\text { - Service user education and empowerment } \\
\text { - Name tags/introductions } \\
\text { - Process for re-entering service } \\
\text { - Length of program } \\
\text { - Public holiday scheduling } \\
\text { - Physiotherapy hours } \\
\text { - Provision \& understanding of information for patients } \\
\text { - Clear roles and respect among team members } \\
\text { - Easy access to rehabilitation specialist knowledge }\end{array}$ & $\begin{array}{l}\text { A service user and staff } \\
\text { designed website that provides } \\
\text { online information about the } \\
\text { range of services provided at the } \\
\text { centre, which can be easily } \\
\text { accessed by the public } \\
\text { (including health professionals). }\end{array}$ & $\begin{array}{l}\text { A short film to raise public awareness of } \\
\text { rehabilitation services and educate people on } \\
\text { how to access services at the centre. A service } \\
\text { user and staff designed information brochure } \\
\text { about the programs, education and services } \\
\text { available at the centre. Appointment scheduling } \\
\text { process reviewed and changed to reduce wait } \\
\text { times for patients between therapy sessions. }\end{array}$ \\
\hline $\begin{array}{l}\text { Adult } \\
\text { Community } \\
\text { Mental Health } \\
\text { Services } \\
\text { (Rural) }\end{array}$ & $\begin{array}{l}\text { - Tools and resources to support recovery planning } \\
\text { - Care coordination } \\
\text { - Education in recovery for clinical staff } \\
\text { - Authentic partnerships } \\
\text { - Working together with other organisations } \\
\text { - Working together with people with a lived experience of } \\
\text { mental illness } \\
\text { - Clinical and community spaces for recovery } \\
\text { - Effective interventions } \\
\text { - Regular reviews } \\
\text { - Support in vulnerable times } \\
\text { - Peer workforce } \\
\text { - Informed decision-making } \\
\text { - Accessible information } \\
\text { - Workforce development } \\
\text { - Technology }\end{array}$ & $\begin{array}{l}\text { Framework for Mental Health } \\
\text { Recovery for specialist adult } \\
\text { community mental health for } \\
\text { the Local Health District. It } \\
\text { supports a shift toward a } \\
\text { targeted, consistent but flexible } \\
\text { approach to stepped care and } \\
\text { support. }\end{array}$ & In process. \\
\hline $\begin{array}{l}\text { Brain Injury } \\
\text { Rehabilitation } \\
\text { (Sub-acute } \\
\text { metropolitan, } \\
\text { rural and } \\
\text { regional) }\end{array}$ & $\begin{array}{l}\text { - Information about the rehabilitation program for service } \\
\text { users for each stage of recovery } \\
\text { - Up-skilling staff (acute/non-acute) about brain injury } \\
\text { - Family inclusion, relational, how to build relationships } \\
\text { with staff } \\
\text { - Partnerships (external/internal) and at transitions of care }\end{array}$ & & $\begin{array}{l}\text { A service user designed information brochure } \\
\text { about recovery following a brain injury for use } \\
\text { in the acute setting. }\end{array}$ \\
\hline $\begin{array}{l}\text { Young People } \\
\text { with Urinary } \\
\text { Incontinence } \\
\text { (Metropolitan, } \\
\text { rural and } \\
\text { regional) }\end{array}$ & $\begin{array}{l}\text { - Time taken to see specialist } \\
\text { - Access to trusted information } \\
\text { - Cost } \\
\text { - Lack of knowledge and empathy in schools } \\
\text { - Impact on family }\end{array}$ & $\begin{array}{l}\text { Interactive resources to increase } \\
\text { knowledge and support teachers } \\
\text { to have conversations with } \\
\text { young people and their families } \\
\text { talk about the management of } \\
\text { the condition at school. } \\
\text { An animation to provide } \\
\text { accessible information on the } \\
\text { scope of urinary incontinence, } \\
\text { common causes and support } \\
\text { strategies for teachers. }\end{array}$ & $\begin{array}{l}\text { Professional guide developed to assist clinicians } \\
\text { managing children and young people with } \\
\text { urinary incontinence in primary health settings. } \\
\text { A guide to facilitate training/support for health } \\
\text { professionals working outside the metropolitan } \\
\text { area who are involved in (or interested in being } \\
\text { involved in) the management of children and } \\
\text { young people with incontinence using } \\
\text { telehealth services. Three pop up pilot clinics } \\
\text { supported by telehealth to provide advice, } \\
\text { support and training to rural clinicians to } \\
\text { improve access and standardise practice. }\end{array}$ \\
\hline $\begin{array}{l}\text { Blood \& Marrow } \\
\text { Transplant Long } \\
\text { Term Follow Up } \\
\text { (LTFU) }\end{array}$ & $\begin{array}{l}\text { - Improved access to exercise equipment \& support } \\
\text { - Clear direction to rehabilitation support services } \\
\text { - Peer support services } \\
\text { - Australian based service user education resources } \\
\text { - Database of services and specialists } \\
\text { - Increasing service capacity } \\
\text { - Increasing coordination of medical, nursing and allied } \\
\text { health services } \\
\text { - 'One stop shop' LTFU clinic. }\end{array}$ & & \\
\hline $\begin{array}{l}\text { Hospitalisation } \\
\text { of People with } \\
\text { Intellectual } \\
\text { Disability } \\
\text { (Metropolitan) }\end{array}$ & $\begin{array}{l}\text { - Service user involvement in care } \\
\text { - Staff training and education } \\
\text { - Admission and transfer of care planning } \\
\text { - Funding for care and equipment } \\
\text { - Physical environment } \\
\text { - Transport } \\
\text { - Communication with clinical staff }\end{array}$ & & $\begin{array}{l}\text { An online resource that guides staff \& other } \\
\text { service providers to better understand and meet } \\
\text { the complex and multiple health needs of people } \\
\text { with an intellectual disability. Stories of lived } \\
\text { experience designed to improve staff knowledge } \\
\text { and skills in caring for people with intellectual } \\
\text { disability. An online toolkit \& personalised folder } \\
\text { to facilitate transfer of relevant and current info } \\
\text { to enable hospital staff to meet the needs of } \\
\text { people with intellectual disability in hospital. }\end{array}$ \\
\hline
\end{tabular}


Table 5. Experience-based co-design principles

\begin{tabular}{|l|l|}
\hline Principle & Description \\
\hline Equal partnership & $\begin{array}{l}\text { Service users, families and health professionals work together from the beginning with an equal } \\
\text { voice and shared ownership and control. }\end{array}$ \\
\hline Openness & Work together on a shared goal, trust the process and learn together. \\
\hline Respect & $\begin{array}{l}\text { Acknowledge and value the views, experiences and diversity of service users, families and health } \\
\text { professionals }\end{array}$ \\
\hline Empathy & $\begin{array}{l}\text { Practice empathy and maintain an environment which feels safe and brings confidence to } \\
\text { everyone. }\end{array}$ \\
\hline Design together & $\begin{array}{l}\text { Service users, families and health professionals work together to design, test, implement and } \\
\text { evaluate improvements, activities, products and services. }\end{array}$ \\
\hline
\end{tabular}

Table 6. Experience-based co-design proposed capabilities: mechanisms of action

\begin{tabular}{|c|c|}
\hline Experience-based co-design capability model & Capabilities \\
\hline \multicolumn{2}{|l|}{ RECOGNITION AND DIALOGUE } \\
\hline $\begin{array}{l}\text { Being: embodying a cooperative mindset to } \\
\text { be accountable for participation }\end{array}$ & $\begin{array}{l}\text { - Recognition that lived-experience of delivering and receiving care, } \\
\text { of conditions and illnesses, is a knowledge that all participants bring } \\
\text { and this is afforded equal value by everyone to other kinds of } \\
\text { knowledge } \\
\text { - Support relational and attitudinal shifts to foster participatory, } \\
\text { equitable and collaborative cultures and mindsets using dialogical } \\
\text { ethics to develop preparedness activities } \\
\text { - Facilitate discussions about values, develop agreements and actions } \\
\text { to address power and relational dynamics } \\
\text { - Acknowledge conflict and work with it in the group to achieve } \\
\text { change } \\
\text { - Identify and address biases for greater cooperative spirit to form }\end{array}$ \\
\hline \multicolumn{2}{|c|}{ COOPERATION, ACCOUNTABLITY AND MOBILISATION } \\
\hline $\begin{array}{l}\text { Knowing: embracing lived-experience } \\
\text { knowledge to mobilise and enact change }\end{array}$ & $\begin{array}{l}\text { - Build knowledge of how to utilise principles that underpin co-design } \\
\text { - Establish high trust relationships as a team of co-designers } \\
\text { - Create shared expectations to enable a sense of accountability for } \\
\text { change and mobilisation } \\
\text { - Identify strategies to support sustained commitment to the co- } \\
\text { design process } \\
\text { - Foster flexibility in participation for co-design that maintains } \\
\text { continuity } \\
\text { - Connect cooperative mindset to a collective spirit to become an } \\
\text { embodied knowledge }\end{array}$ \\
\hline \multicolumn{2}{|c|}{ ENACTMENT, CREATIVITY AND AT'TAINMENT } \\
\hline $\begin{array}{l}\text { Doing: co-design creatively to attain } \\
\text { improvements long term }\end{array}$ & $\begin{array}{l}\text { - Build knowledge of tools and techniques used to enact co-design } \\
\text { - Understand how to purposively match creative techniques and tools } \\
\text { to co-design based on context and purpose } \\
\text { - Empower people to creatively take the action required to make } \\
\text { improvements and attain changes } \\
\text { - Enable enactment through an on-going commitment to working } \\
\text { collaboratively to maximise sustainability of improvements } \\
\text { - Develop implementation strategies to stay focused on improvement }\end{array}$ \\
\hline
\end{tabular}

